\title{
Cadmium (heavy metals) bioremediation by Pseudomonas aeruginosa: a minireview
}

\author{
Edward Raja Chellaiah ${ }^{1}$
}

Received: 11 July 2017 / Accepted: 4 September 2018 / Published online: 11 September 2018

(C) The Author(s) 2018

\begin{abstract}
Heavy metal pollution has become an issue of serious international concern. One of the heavy metal cadmium (Cd) is known to be a widespread environmental contaminant and a potent toxin that may adversely affect human health. Microbial remediation has been applied as an efficient strategy to remove or detoxify the heavy metals mainly from soil, water and sediments, etc. Pseudomonas aeruginosa is one of the most significant bacterium present in almost all contaminated sites. They are often resistant to antibiotics, heavy metals, detergents and organic solvents. This review concluded that $P$. aeruginosa is one of the versatile and high-tolerance cadmium-resistant bacteria isolated from different environment regimens. It can be used as suitable biosorbent for the removal of cadmium and other heavy metals from solution, contaminated waste, water and soil. Apart from this characteristic, $P$. aeruginosa, used as potent bioinoculant, express Plant growth promoting rhizobacteria (PGPR) activity, biofilm and biosurfactant production, and comprise key role in metal phytoextraction process.
\end{abstract}

Keywords Bioremediation $\cdot$ Cadmium $\cdot$ Pseudomonas aeruginosa $\cdot$ Resistance bacteria $\cdot$ Mechanisms

\section{Introduction}

Environmental pollution is the presence of a pollutant in the environment: air, water and soil, which may be lethal or toxic and will cause harmful to living things in the polluted environment (Duruibe et al. 2007). Heavy metal pollution occurs directly by effluent outfalls from industries, refineries and waste treatment plants and indirectly by the contaminants that enter the water supply from soils/ground water systems and from the atmosphere via rainwater (Vijayaraghavan and Yun 2008).

Cadmium (Cd) is identified as major pollutant, nonessential metals, and it is harmful to organisms at relatively low concentrations about $0.001-0.1 \mathrm{mg} / \mathrm{L}$ (Alkorta et al. 2004; Tang et al. 2006). Cd is widely applied in many industries like chlor-alkali, paints, electroplating, and copper alloys, pulp and paper, alkaline batteries, and mining, fertilizer and zinc refining (USEPA 2000). Cd enters into human and animal body through food chain that can cause

Edward Raja Chellaiah

edwardrajac@gmail.com; edwardrajac@rediffmail.com

1 DST-Ramanujan Fellow, Department of Molecular Biology, School of Biological Sciences, Madurai Kamaraj University, Madurai 625 021, Tamil Nadu, India severe diseases (Zeng et al.2009). Cadmium is not involved in any known biological processes, and it is known to disturb enzyme activities, to inhibit the DNA-mediated transformation in microorganisms, to interfere in the symbiosis between microbes and plants, as well as to increase plant predisposition to fungal invasion (Kabata-Pendias and Pendias 2001). The accumulation of $\mathrm{Cd}$ in plants may cause several physiological, biochemical and structural changes (Khan et al. 2007; Feng et al. 2010) such as alters mineral nutrients uptake (Hossain et al. 2010), disturbs the Calvin cycle enzymes, photosynthesis and carbohydrate metabolism (Mobin and Khan 2007; Hossain et al. 2010) changes the antioxidant metabolism (Khan et al. 2009), and lowers the crop productivity (di Toppi and Gabbrielli 1999).

\section{Heavy metals removal methods}

Many conventional methods have been applied in order to remove heavy metals from aqueous streams. Among the most commonly used techniques are chemical precipitation, chemical oxidation and reduction, ion-exchange, filtration, electrochemical treatment, reverse osmosis, evaporative recovery and solvent extraction (Xia and Liyuan 2002). These conventional techniques offered several problems such 
as unpredictable metal ions removal and generation of toxic sludge (Xia and Liyuan 2002).

Bioremediation is an alternative option to use of natural and recombinant microorganisms for the removal/reduction of toxic pollutants. It is considered as cost-effective and environment friendly approach (Brar et al. 2006). The living and dead biomass of microbes have been used for the efficient removal of metal ions through biosorption and bioaccumulation process (Chojnacka 2010; Joutey et al. 2015). Bioaccumulation is a dependent, active and partially reversible process that needs energy and requires respiration. In contrast, biosorption is an independent, revisable process that does not require energy/respiration (Vijayaraghavan and Yun 2008; Velásquez and Dussan 2009). The major advantage of biosorption is low operating cost, high ability, possibility of metal recovery and potent biosorbent revival (Volesky 2001; Göksungur et al. 2005).

\section{Review bacterium Pseudomonas aeruginosa}

Pseudomonas species is ubiquitous in soil, water ecosystems and are capable of metabolizing a wide range of organic and inorganic compounds. In addition, Pseudomonas was wellstudied and showed high resistance to antibiotics, heavy metals and detergents and organic solvents (Pardo et al. 2003; Ansari and Malik 2007; Haritash and Kaushik 2009). P. aeruginosa is a gram-negative, rod-shaped bacterium. It is found in desert, agricultural, grassland, and forest soils, water and humans, plants, sewage and hospitals (Green et al. 1974; Lederberg 2000; Drees 2004) as well as in riverine ecosystems (Pellet et al. 1983) and metal-contaminated sites (Bodour et al. 2003). The application of P. aeruginosa in cadmium bioremediation is shown in Fig. 1.

\section{Cadmium resistance mechanism of $P$. aeruginosa}

Microbial Cd resistance was exhibited in at least six different ways. These include deposition of the toxic metal in the cell wall, altered accumulation of the toxic compound and alternation of the cell wall plasma membrane complex (Mitra and Bernstein 1977). Cd can enter bacterial cells through divalent cation uptake systems such as $\mathrm{Mn}^{2+}$ (Tynecka et al. 1981) or $\mathrm{Zn}^{2+}$ (Laddaga and Silver 1985), gene amplification (Beach and Palmiter 1981), active Cd efflux (Tynecka et al. 1981) and enhanced transcription of metallothionein genes (McEntee et al. 1986).

At first, one of the best characterized bacterial Cd resistance mechanisms was identified in gram-positive bacteria determined by the Cd-transporting ATPase (Silver and Phung 1996). In gram-negative bacteria, Cd is detoxified by RND-driven systems like Czc, which is mainly a zinc exporter (Nies and Silver 1989). A well characterized

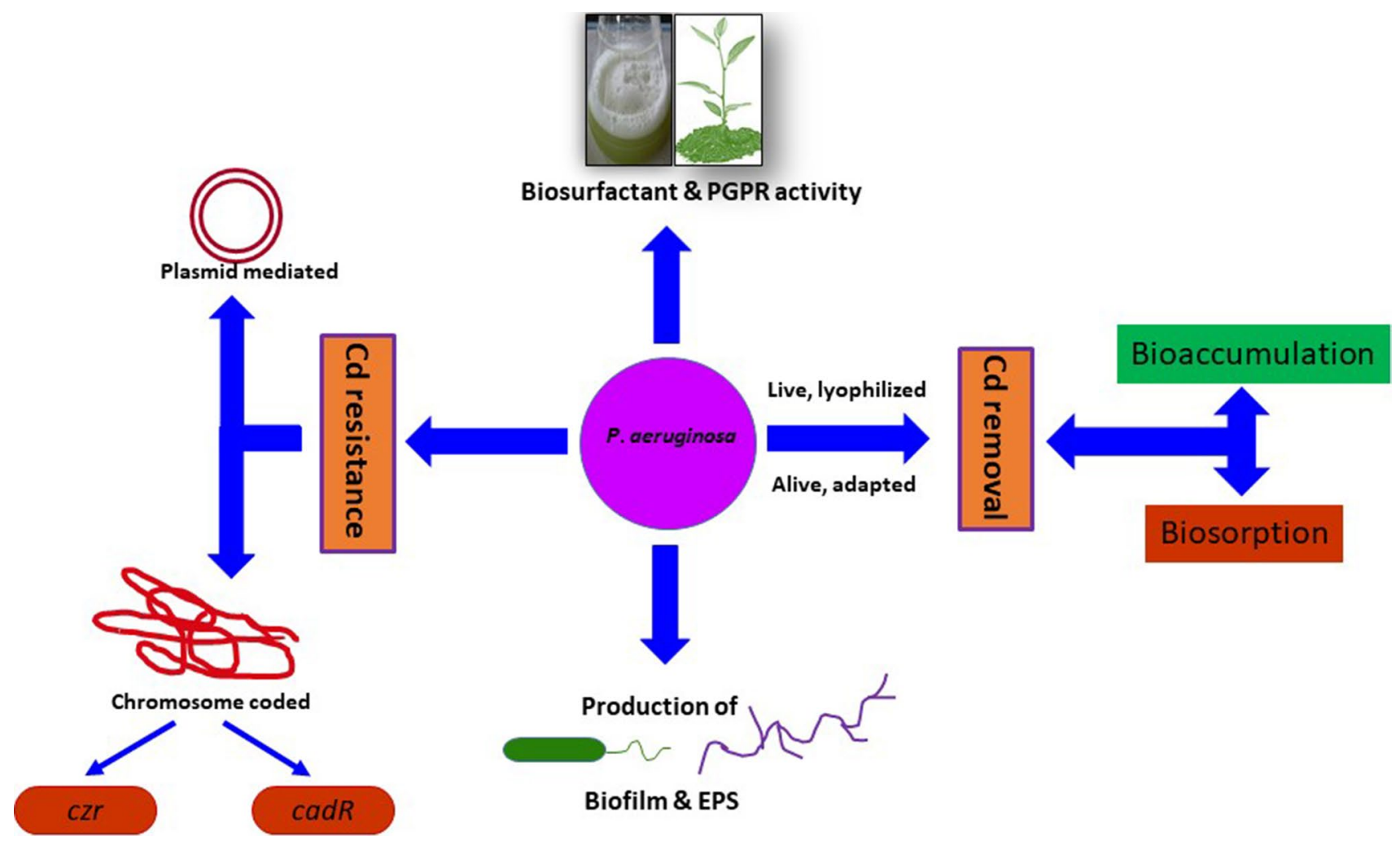

Fig. 1 Schematic representation of P. aeruginosa used in cadmium bioremediation 
Cd-resistant system was identified in Alcaligenes eutrophus $\mathrm{CH} 34$. The gram-negative bacterium showed $\mathrm{Cd}, \mathrm{Zn}$ and $\mathrm{Co}$ resistance was plasmid encoded with the $c z c$ gene cluster (Nies et al. 1989). The homologous of gene cluster ( $c z c)$ called $c z r$ was identified in the chromosome of $P$. aeruginosa CMG103. The predicted CzrC, CzrB and CzrA proteins encoded by the CMG103 czrCBA genes show significant similarities with the proteins encoded by A. eutrophus $\mathrm{CH} 34$ and also czcCBA which determines a cation-antiporter efflux system for metal resistance. The establishments of the $c z c$ and $c z r$ gene clusters regarding regulatory modules are different. Moreover, in A. eutrophus, $\mathrm{CH} 34$ and related strains $c z c$ were plasmid borne, whereas $c z r$ was chromosomal coded resistance in $P$. aeruginosa CMG103 (Hassan et al. 1999). The amplification of the gene by using the chromosomal DNA indicates the presence of the cadmium-resistant gene on the chromosomal DNA and sequencing of the fragment confirmed the presence of czcA gene responsible for cadmium resistance (efflux pump) in EP-Cd1 (Muneer et al. 2016).

Two contrary transcribed genes $c a d A$ and $c a d R$ were identified in the chromosome of P. putida 06909. CadA was similar to $\mathrm{Cd}$-transporting ATPases that is mainly from gram-positive bacteria, and to $\mathrm{ZntA}, \mathrm{Pb}, \mathrm{Zn}$ and Cd-transporting ATPase from E. coli cadR (Lee et al. 2001). CadR from $P$. aeruginosa encodes a transcriptional regulatory protein which responds $\mathrm{Cd}(\mathrm{II}) \gg \mathrm{Zn}(\mathrm{II})>\mathrm{Hg}$ (II) at its cognate promoter PcadA. CadR will also act to induce transcription at the E. coli ZntR cognate promoter PzntA (Brocklehurst et al. 2003). In addition, $c a d R$ was also found in the chromosome of environmental isolate $P$. aeruginosa $\mathrm{BC} 15$. Multiple nucleotide sequence alignments of $c a d R$ showed high homology with $P$. aeruginosa FLH033011 (100\%), $P$. aeruginosa PAO1 (99\%), and $P$. aeruginosa UCBPP-PA14 (98\%), respectively (Edward Raja and Selvam 2012).

\section{Plasmid-mediated cadmium resistance of $P$. aeruginosa}

Microbial survival in the polluted environments depends on inherent biochemical, structural properties, physiological and/or genetic adaptation (Wuertz and Mergeay 1997). Various studies have been published of different heavy metalresistant mechanisms found in the genus Pseudomonas, as well as reports of chromosome and plasmid-encoded genetic determinants for resistance to heavy metals (Coral et al. 2006).

Pseudomonas aeruginosa RA65 ( $9.5 \mathrm{~kb})$ plasmidencoded resistance to $\mathrm{Cd}, \mathrm{Zn}$ and $\mathrm{Pb}$ was confirmed by agarose gel and transformation analysis (Mohamed and AboAmer 2012). This finding was similar to the results reported that $100 \%$ of plasmid-mediated, resistant $P$. aeruginosa strains were isolated from heavy metal-contaminated regions
(Pacheco et al. 1995). Likewise, El-Sayed et al. (2008) reported that plasmid $(27.491 \mathrm{~Kb})$-mediated Cd-resistant Pseudomonas species was isolated from Sohag Governorate, Egypt. Also (60 kb) plasmid-mediated heavy metals resistance including $\mathrm{Cd}$ was identified in $P$. aeruginosa AA301 isolated Egyptian soil (Abo-Amer and Mohamed 2006). Cadmium-resistant $P$. aeruginosa EP-Cd1 harboured $23 \mathrm{~kb}$ plasmids (Muneer et al. 2016). The same size plasmid DNA was detected in $\mathrm{Pb}-, \mathrm{Cr}-, \mathrm{Cd}-$ and Ti-resistant $P$. aeruginosa (Kassab and Roane 2006; Park et al. 2006). P. aeruginosa tested for its multiple metal resistances was found to be plasmid mediated evidenced by Hassen et al. (2008) and Edward Raja and Selvam (2009). In general, the incidence of plasmid carrying bacteria is higher in metal polluted sites than in the unpolluted regions (Malik and Jaiswal 2004).

\section{Pseudomonas aeruginosa as cadmium resistant}

The importance of Pseudomonads in nutrient cycling and their ability to quickly adapt to the contaminated environments make them preferential choice for eco-friendly studies. The first concept was supported by reports of the key role of Pseudomonads in the heterotrophic mineralization of organic carbon and in denitrification (Bollag and Barabasz 1979). Then latter was supported by the tendency of this genus to develop novel enzymatic pathways which may contribute to its adaptability to harsh environments (Clarke and Ornston 1975). Therefore, Pseudomonads are abundant in a variety of contaminated environments including $\mathrm{Cd}$ and $\mathrm{Hg}$-polluted water and sediments (Houba and Remacle 1980).

Many researchers have reported that $P$. aeruginosa as Cd-resistant bacteria was isolated from different environment regions (Table 1). Microorganisms resistant to antibiotics and metals appear to be the result of exposure to metal-contaminated environments that cause coincidental selection of resistance factors for both antibiotics and heavy metals (Spain 2003). Cd-tolerant $P$. aeruginosa was resistant to a wide array of antibiotics, and heavy metal resistance is shown in Table 2. P. aeruginosa $\mathrm{S} 6$ with a relatively high minimum inhibitory concentration (MIC) for metals and a large spectrum antibiotic resistance appears to be a bacterial model for ecotoxicological studies (Hassen et al. 1998). The ability of biochemical and molecular methods was used to identify and characterize natural culturable bacterial community screened from polluted environment and then applied for potential exploitation of metal-resistant bacterial strains in bioremediation process (Chovanova et al. 2004).

\section{Cadmium stress protein}

Exposure of bacteria to heavy metals leads to altered expression of genes involved in metal transport as well 
Table 1 Cadmium-resistant $P$. aeruginosa isolated from different environment regions

\begin{tabular}{|c|c|c|c|c|}
\hline Strains/isolates & $\begin{array}{l}\text { MIC of Cd } \\
(\mathrm{mM} / \mathrm{mg} / \mathrm{L})\end{array}$ & Isolation site & Bioremediation characteristics & References \\
\hline Clinical strain & 2.18 & Clinical lesions & - & Nakahara et al. (1997) \\
\hline Strain G-1 & 4.3 & Activated sludge & - & Hiroyuki and Haruyasu (1980) \\
\hline ATCC 27853 & $1,0.5$ & - & - & Gelmi et al. (1994) \\
\hline Strain CW961 & 5 & Deep sea vent & Biosorption & Wang et al. (1997) \\
\hline Strain PU21 & - & Hospital Sewage & Biosorption & Chang et al. (1997) \\
\hline P. aeruginosa & 2 & Sewage & - & Filali et al. (2000) \\
\hline P. aeruginosa & 1.09 & Irrigated agricultural soil & - & Ansari and Malik (2007) \\
\hline Strain BC15 & 6 & Oil mill-treated wastewater & Biosorption & Edward Raja et al. (2008) \\
\hline Strain E1 & 18 & $\mathrm{Cd}$ contaminated soil & Biosorption & Zeng et al. (2009) \\
\hline Strain JP-11 & 6.8 & Marine & Bioremoval & Chakraborty and Das (2014) \\
\hline Strains SN1, SN3 & $9.2,9.8$ & Contaminated soil & - & Nath et al. (2014) \\
\hline P. aeruginosa & 5.18 & Hospital wastewater & - & Yamina et al. (2014) \\
\hline P. aeruginosa & 0.5 & Mine tailing & PGPR/bioinoculant/Phytoextraction & Aka and Babalola (2016) \\
\hline P. aeruginosa & 12 & Cd contaminated rice field & $\begin{array}{l}\text { Bioaccumulation } \\
\text { Bioadsorption }\end{array}$ & Lin et al. (2016) \\
\hline P. aeruginosa & $900 \mathrm{mg} / \mathrm{L}$ & Soil & Adsorption & Ghaima et al. (2017) \\
\hline P. aeruginosa & - & Contaminated soil & & Karimpour et al. (2018) \\
\hline
\end{tabular}

MIC Minimal inhibitory concentration

as other stress responses such as heat shock and oxidative stress (Blom et al. 1992). In general, exposure of bacteria to low levels of one stress can induce a consequent increase in resistance to the same (adaptive) or unrelated (cross-protection) stress (Mongkolsuk et al. 1997). The induction studies of $P$. aeruginosa BC15 with sub-lethal concentrations of $\mathrm{Cd}$ induced adaptive resistance to lethal doses of $\mathrm{Cd}$. Cd-induced cells also showed cross-resistance to lethal concentration of zinc (Edward Raja et al. 2008). Upon growth in $\mathrm{Cd}$ and $\mathrm{Pb}$ supplemented plates, Pseudomonas S8A exhibited both exopolymer and biosurfactant production. They also displayed two morphologically distinct colony subtypes such as small and round or large and flat. The large morphotype produced greater amounts of surfactant than the small morphotype. It suggests that a unique subpopulation response to Cd toxicity and an unidentified $28 \mathrm{kDa}$ protein was expressed when exposure to $>10 \mathrm{mg} / \mathrm{L} \mathrm{Cd}$ (Kassab and Roane 2006). Under Cd stress, Pseudomonas sp. M3 expressed $25 \mathrm{kDa}$ protein (Abbas et al. 2014), and in contrast, three high molecular weights proteins (208, 78 and $33.5 \mathrm{KD})$ were lost, while low molecular weight protein $(2.5 \mathrm{KD})$ was induced for Pseudomonas isolates screened from Egyptian soil (El-Sayed et al. 2008). Under Cd stress, different molecular weight proteins were detected in supernatant as well as in the cell lysate of $P$. aeruginosa EP-Cd1 (Muneer et al. 2016).

\section{Cadmium bioremoval}

Several studies have been reported the ability of gramnegative bacteria to resist and accumulate $\mathrm{Cd}$ ions (Higham et al. 1984; Macaskie et al. 1987; Beveridge 1989; Gelmi et al. 1994; Wang et al. 1997). P. aeruginosa PU21 biomass appears an effective bioadsorbent for the removal and recovery of $\mathrm{Cd}, \mathrm{Cu}$ and $\mathrm{Pb}$ from polluted water (Chang et al. 1997). Likewise, dead cell biomass of $P$. aeruginosa has a high ability to adsorption of $\mathrm{Cd}$ and $\mathrm{Pb}$ in aqueous solutions (Karimpour et al. 2018). In contrast, live cells of Pseudomonas BC15 was also capable of biosorbing $\mathrm{Cd}$ along with other metals such as $\mathrm{Pb}, \mathrm{Ni}$ and $\mathrm{Cr}$ in a medium (Edward Raja et al. 2006). Zeng et al. (2009) also concluded that $P$. aeruginosa E1 living cell has performed better biosorption of $\mathrm{Cd}$ than non-living cells. The lyophilized cells of $P$. aeruginosa PAO1 adsorbed $\mathrm{Cd}$ from aqueous solution was estimated at acidic pH 5-6 (Peter et al. 2014). In another study, $P$. aeruginosa isolated from active sludge could efficiently remove $94.7 \% \mathrm{Cd}$ from solution within $60 \mathrm{~min}$ (Kermani et al. 2010). During biosorption studies, adapted cells of $P$. aeruginosa strain JCM 5962 and genetically engineered (GE) $P$. aeruginosa also able to remove Cd (Bojorquez et al. 2016; Tang et al. 2018). Recently published strain Pseudomonas aeruginosa san ai is a promising candidate for cadmium bioremediation because of its large biosorption potential (Zivkovic et al. 2018). 
Table 2 Co selection of heavy metals and antibiotic resistances of P. aeruginosa

\begin{tabular}{|c|c|c|}
\hline Cadmium and other metal resistances & Antibiotic resistance & References \\
\hline $\mathrm{Cd}, \mathrm{As}, \mathrm{Hg}$ & $\begin{array}{l}\text { Chloramphenicol, dibekacin, gentamycin, kanamycin, streptomycin, } \\
\text { tetracycline }\end{array}$ & Nakahara et al. (1997) \\
\hline $\mathrm{Cd}, \mathrm{Cr}, \mathrm{Cu}, \mathrm{Hg}$ & - & Hiroyuki and Haruyasu (1980) \\
\hline $\mathrm{Cd}, \mathrm{Cr}, \mathrm{Ni}, \mathrm{Pb}, \mathrm{Zn}$ & $\begin{array}{l}\text { Ampicillin, chloramphenicol, erythromycin, kanamycin, streptomycin, } \\
\text { tetracycline }\end{array}$ & Edward Raja et al. (2006) \\
\hline $\mathrm{Cd}, \mathrm{Cu}, \mathrm{Pb}$ & - & Chang et al. (1997) \\
\hline $\mathrm{Cd}$ & - & Wang et al. (1997) \\
\hline $\mathrm{Cd}, \mathrm{Co}, \mathrm{Cu}, \mathrm{Ba}, \mathrm{Ag}, \mathrm{Hg}, \mathrm{La}, \mathrm{Li}$ & - & Filali et al. (2000) \\
\hline $\mathrm{Cd}$ & - & Kassab and Roane (2006) \\
\hline $\mathrm{Cd}, \mathrm{Cu}, \mathrm{Ni}, \mathrm{Pb}, \mathrm{Zn}, \mathrm{Hg}$ & - & Ansari and Malik (2007) \\
\hline $\mathrm{Cd}, \mathrm{Cr}, \mathrm{Co}, \mathrm{Cu}, \mathrm{Ni}, \mathrm{Pb}, \mathrm{Zn}$ & Ceftazidime, gentamycin, neomycin, norfloxacin, ofloxacin, vancomycin & Hassen et al. (2008) \\
\hline $\mathrm{Cd}, \mathrm{Co}, \mathrm{Cu}, \mathrm{Mn}, \mathrm{Pb}, \mathrm{Zn}$ & $\begin{array}{l}\text { Amikacin, ampicillin, chloramphenicol, erythromycin, kitasamycin, } \\
\text { nalidixic acid, neomycin, novobiocin, penicillin, polymyxin, strepto- } \\
\text { mycin, tetracycline }\end{array}$ & Zeng et al. (2009) \\
\hline $\mathrm{Cd}, \mathrm{Cr}, \mathrm{Co}, \mathrm{Cu}, \mathrm{Mn}, \mathrm{Ni}, \mathrm{Zn}$ & - & Sinha and Mukherjee (2009) \\
\hline $\mathrm{Cd}, \mathrm{Co}, \mathrm{Cu}, \mathrm{Ni}$ & - & Choudhary and Sar (2009) \\
\hline $\mathrm{Cd}, \mathrm{Cu}, \mathrm{Pb}$ & - & Chang et al. (1997) \\
\hline $\mathrm{Cd}$ & - & Kermani et al. (2010) \\
\hline $\mathrm{Cd}, \mathrm{Te}$ & - & Chien et al. (2011) \\
\hline $\mathrm{Cd}, \mathrm{Cr}, \mathrm{Cu}, \mathrm{Pb}, \mathrm{Ni}, \mathrm{Zn}$ & Amoxicillin, cephalexin, erythromycin, penicillin, streptomycin & Chien et al. (2013) \\
\hline $\mathrm{Cd}$ & - & Abbas et al. (2014) \\
\hline $\mathrm{Cd}, \mathrm{Cu}, \mathrm{Zn}$ & $\begin{array}{l}\text { Amikacin, ampicillin, amoxicillin, ciproflaxin, neomycin, tetracycline, } \\
\text { vancomycin }\end{array}$ & Chen et al. (2014) \\
\hline $\mathrm{Cd}, \mathrm{Cr}, \mathrm{As}, \mathrm{Hg}, \mathrm{Pb}, \mathrm{Ni}, \mathrm{Zn}$ & - & Chakraborty and Das (2014) \\
\hline $\mathrm{Cd}, \mathrm{Pb}$ & Kanamycin, oxacillin, nalidixic acid, Sulfonamides & Nath et al. (2014) \\
\hline $\mathrm{Cd}, \mathrm{Hg}, \mathrm{Zn}$ & - & Yamina et al. (2014) \\
\hline $\mathrm{Cd}, \mathrm{Cr}, \mathrm{Ni}$ & - & Aka and Babola (2016) \\
\hline $\mathrm{Cd}, \mathrm{Pb}, \mathrm{Zn}$ & - & Lin et al. (2016) \\
\hline $\mathrm{Cd}, \mathrm{Cu}, \mathrm{Zn}$ & - & Chen et al. (2016) \\
\hline
\end{tabular}

\section{Biofilm, EPS production by $P$. aeruginosa}

Biofilm EPS is a rich matrix of polysaccharides, proteins and nucleic acids (Mangwani et al. 2014). In addition, biofilm and extracellular polymeric substances (EPS) production is important for the bacterial resistance against heavy metals. Biosorption or bioaccumulation of heavy metals by EPS production from Pseudomonas also can contribute to bacterial heavy metal resistance (Kilic and Dönmez 2008). Also, recently published high Cd-resistant $(7.2 \mathrm{mM}) P$. aeruginosa san ai previously used in various environmental studies like heavy metal removal, rhamnolipid and exopolysaccharide (EPS) production (Zivkovic et al. 2018). Pseudomonas sp. EJ01 was able to tolerate $\mathrm{Cd}$ in growth medium and exhibits aggregated and forming biofilm at $2 \mathrm{mM} \mathrm{Cd}$ and above concentration. This phenomenon might be related to the bacterium's ability to produce exopolysaccharides (Chien et al. 2013). In another study, biofilm producing marine bacterium $P$. aeruginosa JP-11 showed resistance to $\mathrm{Cd}$ up to $1000 \mathrm{ppm}$ in aerobic conditions. The strain possesses czcABC genes for cadmium resistance as reported (Chakraborty and Das 2014) in other P. aeruginosa strain E1 to efflux out the $\mathrm{Cd}$ (Zeng et al. 2012). This gene encodes proteins expressing ion transporters by which metal ions can be pumped out of cytoplasm (Nies 1992). Chakraborty and Das (2014) proved the Cd resistance though efflux mechanism as well as removal of $\mathrm{Cd}$ by binding to its biofilm EPS. The czcABC gene is known for encoding proteins showing resistance to Cd, Co and Zn (Nies 1992).

\section{P. aeruginosa act as biosurfactant}

Biosurfactants are surfactants produced or secreted by living organisms such as microbes. Many studies have been reported that biosurfactants are able to complex and remediate heavy metals such as $\mathrm{Cd}, \mathrm{Pb}$ and $\mathrm{Zn}$ (Maier and Soberón-Chávez 2000; Mulligan 2005). Rhamnolipids are a class of biosurfactant produced by P. aeruginosa and (Maier 
and Soberón-Chávez 2000) potential applications in industry and as additives for environmental remediation (Müller et al. 2012). An attempt was made to evaluate potential relationships between rhamnolipid production and the presence of heavy metals. In this finding, the influence of $\mathrm{Cd}$ on rhamnolipid (RL) synthesis was produced by $P$. aeruginosa. Cd-induced $r h l B$ expression was observed in mid-stationary phase $(53 \mathrm{~h})$ and sustained production of rhamnolipid completed in 96-h late stationary growth phase. But Neilson et al. (2010) found that most significant was an observed increase in the ratio of RL2 to RL1 congeners produced by $P$. aeruginosa cultures grown in the presence of $\mathrm{Cd}$. These data combined with previously published work documenting strong complexation constants between rhamnolipid and various heavy metals (Ochoa-Loza et al. 2001; Neilson et al. 2003).

\section{P. aeruginosa as PGPR and bioinoculant}

Plant growth-promoting rhizobacteria (PGPR) are beneficial, naturally occurring and free living bacteria that colonize the plant rhizosphere (Kloepper et al. 2001; Bullied et al. 2002). Many fluorescent Pseudomonas strains, for example, P. aeruginosa which colonize the rhizosphere exert a protective effect on the roots through the production of in situ antibiotic compounds that promote growth and inhibit microbial infections (Jenni et al. 1989; Wackett 2000). Bioaugmentation is a promising method for assisting phytoextraction of heavy metals from contaminated soil. In addition, phytoextraction is cheap and environmentally compatible process. PGPR characteristics of $P$. aeruginosa are shown in Table 3. In several studies, metal tolerant bacteria including Pseudomonas species can be isolated and selected for their potential to promote plant growth and heavy metal accumulation by plants (Sheng et al. 2008; Rajkumar and Freitas 2008; Aka and Babalola 2016). They can develop metal bioavailability and provide protection to plants against the toxic effects of heavy metals using a variety of processes with biosorption, bioaccumulation and biotransformation (Yang et al. 2005). Aka and Babalola (2016) revealed that inoculation with metal tolerant bacteria not only protects plants against the toxic effects of heavy metals, but also increases growth and metal accumulation of plants significantly. In another study, $S$. nigrum combined with Cd-tolerant $P$. aeruginosa strains ZGKD5 and ZGKD2 might have the potential to improve $\mathrm{Cd}$ phytoextraction efficiency in farmland soils contaminated with low levels of Cd (Shi et al. 2016). Besides, the inoculation of Cd-polluted soil with genetically engineered Psew-MT significantly elevated the shoot and root biomass and leaf chlorophyll content. Likewise, plants inoculated with Pse-w-MT proved significantly lower $\mathrm{Cd}$ accumulation in the root and shoot system (Huang et al. 2016).

\section{Conclusion}

In conclusion, $P$. aeruginosa expresses its attitudes like $\mathrm{Cd}$ resistant, bioremoval (biosorption, bioaccumulation) characteristics, heavy metal and antibiotic resistances, adaptive and cross-resistance, PGPR activity and biofilm formation, biosurfactant and EPS production, bioinoculant and phytoextraction process. The above-mentioned features were confirming and proved that $P$. aeruginos $a$ is one of the most suitable bacterium or more appropriate choice for cadmium bioremediation.

In addition, the problems and prospects in the practical application and research of $P$. aeruginosa are a typical example of dual debt in a scientific environment, and it is one of the most substantial opportunistic pathogen and is responsible for the majority of nosocomial infections.

Table 3 PGPR characteristics of Cd-resistant Pseudomonas aeruginosa

\begin{tabular}{|c|c|c|c|}
\hline Cd-resistant PGPR & PGPR traits & Plants & References \\
\hline P. aeruginosa & - & $\begin{array}{l}\text { Abelmoschus esculentus L. (okra), Lycopersicon esculen- } \\
\text { tum L. (tomato), Amaranthus sp. (African spinach) }\end{array}$ & $\begin{array}{l}\text { Adesemoye et al. (2008), } \\
\text { Adesemoye and Ugoji } \\
\text { (2009) }\end{array}$ \\
\hline P. aeruginosa & Siderophores & - & Braud et al. (2009) \\
\hline $\begin{array}{l}\text { P. aeruginosa } \\
\text { 4EA }\end{array}$ & Siderophores & - & Naik and Dubey (2011) \\
\hline P. aeruginosa & $\begin{array}{l}\text { IAA, } \mathrm{HCN}, \mathrm{NH}_{4} \text {, sidero- } \\
\text { phores, exopolysaccha- } \\
\text { rides, } \mathrm{PSB}\end{array}$ & Vigna radiata & Ahemad and Khan (2010) \\
\hline $\begin{array}{l}\text { P. aeruginosa } \\
\text { ZGKD5, ZGKD2 }\end{array}$ & $\begin{array}{l}\text { IAA, siderophores, } \mathrm{NH}_{4} \text {, } \\
\text { biosurfactant, } \mathrm{PSB}, \mathrm{N}_{2} \\
\text { fixation activity }\end{array}$ & S. nigrum & Shi et al. (2016) \\
\hline $\begin{array}{l}\text { P. aeruginosa } \\
\text { (Pse-w) }\end{array}$ & $\begin{array}{l}\text { IAA, siderophore } \\
\text { PSB }\end{array}$ & Pisum sativum $\mathrm{L}$. & Huang et al. (2016) \\
\hline
\end{tabular}

$I A A$ indole acetic acid, $P S B$ phosphate solubilizing bacteria 
Nevertheless, in the field of environmental protection, the human health concerns of this bacterium are not predictable, and the strains of this species are commonly used for bioremediation resolutions.

Open Access This article is distributed under the terms of the Creative Commons Attribution 4.0 International License (http://creativeco mmons.org/licenses/by/4.0/), which permits unrestricted use, distribution, and reproduction in any medium, provided you give appropriate credit to the original author(s) and the source, provide a link to the Creative Commons license, and indicate if changes were made.

\section{References}

Abbas SZ, Rafatullah M, Ismail N, Lalung J (2014) Isolation, identification, and characterization of cadmium resistant Pseudomonas sp. M3 from industrial wastewater. J Waste Manag. https://doi. org/10.1155/2014/160398

Abo-Amer AE, Mohamed RM (2006) Heavy metals resistant plasmid-mediated utilization of solar by Pseudomonas aeruginosa AA301. Roum Arch Microbiol Immunol 65:113-119

Adesemoye AO, Obini M, Ugoji EO (2008) Comparison of plant growth-promotion with Pseudomonas aeruginosa and Bacillus subtilis in three vegetables. Braz J Microbiol 39(3):423-426

Adesemoye AO, Ugoji EO (2009) Evaluating Pseudomonas aeruginosa as plant growth-promoting rhizobacteria in West Africa. Arch Phytopathol plant Protect 42:188-200

Ahemad M, Khan MS (2010) Phosphate-solubilizing and plant growthpromoting Pseudomonas aeruginosa PS1 improves greengram performance in quizalafop-p-ethyl and clodinafop amended soil. Arch Environ Contam Toxicol 58:361-372

Aka RJN, Babalola OO (2016) Effect of bacterial inoculation of strains of Pseudomonas aeruginosa, Alcaligenes feacalis and Bacillus subtilis on germination, growth and heavy metal $(\mathrm{Cd}, \mathrm{Cr}$, and Ni) uptake of Brassica juncea. Int J Phytoremediat 8:200-209

Alkorta I, Hernandez-Allica J, Becerril JM, Amezaga I, Albizu I, Garbisu I (2004) Recent findings on the phytoremediation of soils contaminated with environmentally toxic heavy metals and metalloids such as zinc, cadmium, lead and arsenic. Rev Environ Sci Biotechnol 3:71-90

Ansari MI, Malik A (2007) Biosorption of nickel and cadmium by metal resistant bacterial isolates from agricultural soil irrigated with industrial wastewater. Bioresour Technol 98:3149-3153

Beach LR, Palmiter RD (1981) Amplification of the metallothionein-1 gene in cadmium-resistant mouse cells. PNAS 78:2110-2114

Beveridge TJ (1989) Metal ions and bacteria. In: Beveridge TJ, Doyle RJ (eds) Metal ions and bacteria. Wiley, New York, pp 1-19

Blom A, Harder W, Matin A (1992) Unique and overlapping pollutant stress proteins of Escherichia coli. Appl Environ Microbiol 58:331-334

Bodour AA, Drees KP, Maier RM (2003) Distribution of biosurfactant producing bacteria in undisturbed and contaminated arid southwestern soils. Appl Environ Microbiol 69:3280-3287

Bojorquez C, Frias Espericueta MG, Voltolina D (2016) Removal of cadmium and lead by adapted strains of Pseudomonas aeruginosa and Enterobacter cloacae. Rev Int Contam Ambie 32:407-412

Bollag JM, Barabasz W (1979) Effect of heavy metal on denitrification process in soil. J Environ Qual 8:196-201

Brar SK, Verma M, Surampalli RY, Misra K, Tyagi RD, Meunier N, Blais JF (2006) Bioremediation of hazardous wastes-a review. Pract Period Hazard Toxic Radioact Waste Manag 10:59-72
Braud A, Jézéquel K, Bazot S, Lebeau T (2009) Enhanced phytoextraction of an agricultural $\mathrm{Cr}$ - and $\mathrm{Pb}$-contaminated soil by bioaugmentation with siderophore-producing bacteria. Chemosphere 74(2):280-286

Brocklehurst KR, Megit SJ, Morby AP (2003) Characterization of CadR from Pseudomonas aeruginosa: a Cd(II)-responsive MerR homologue. Biochem Biophys Res Commun 308:234-239

Bullied WJ, Buss TJ, Vessey JK (2002) Bacillus cereus UW85 inoculation effects on growth, nodulation, and $\mathrm{N}$ accumulation in grain legumes: field studies. Can J Plant Sci 82:291-298

Chakraborty J, Das S (2014) Characterization and cadmium-resistant gene expression of biofilm-forming marine bacterium Pseudomonas aeruginosa JP-11. Environ Sci Pollut Res 21:14188-14201

Chang JS, Law R, Chang CC (1997) Biosorption of lead, copper and cadmium by biomass of Pseudomonas aeruginosa PU21. Water Res 31:1651-1658

Chen L, Luo S, Li X, Wan Y, Chen J, Liu C (2014) Interaction of Cdhyperaccumulator Solanum nigrum L. and functional endophyte Pseudomonas sp. Lk9 on soil heavy metals uptake. Soil Biol Biochem 68:300-308

Chen B, Stein AF, Castell N, Gonzalez-Castanedo Y, Sanchez de la Campa AM, de la Rosa JD (2016) Modeling and evaluation of urban pollution events of atmospheric heavy metals from a large $\mathrm{Cu}$-smelter. Sci Total Environ 539:17-25

Chien CC, Jiang MH, Tsai MR, Chien CC (2011) Isolation and characterization of an environmental cadmium and tellurite resistant Pseudomonas strain. Environ Toxicol Chem 30:2202-2207

Chien CC, Lin BC, Wu CH (2013) Biofilm formation and heavy metal resistance by an environmental Pseudomonas sp. Biochem Eng J 78:132-137

Chojnacka K (2010) Biosorption and bioaccumulation the prospects for practical applications. Environ Int 36:299-307

Choudhary S, Sar P (2009) Characterization of a metal resistant Pseudomonas sp. isolated from uranium mine for its potential in heavy metal $(\mathrm{Ni} 2+, \mathrm{Co} 2+, \mathrm{Cu} 2+$, and $\mathrm{Cd} 2+)$ sequestration. Bioresour Technol 100(9):2482-2492

Chovanova K, Sladekova D, Kmet V, Proksova M, Harichova J, Puskarova A, Polek B, Feriance P (2004) Identification and characterization of eight cadmium resistant bacterial isolates from a cadmium contaminated sewage sludge. Biologia 59:817-827

Clarke PH, Ornston N (1975) Metabolic pathways and regulation II. In: Clarke PH, Richmond MH (eds) Genetics and bio-chemistry of Pseudomonas. Wiley, London, pp 263-340

Coral G, Arikan B, Coral MNU (2006) A preliminary study on tellurite resistance in Pseudomonas spp. isolated from hospital sewage. Pol J Environ Stud 15:517-520

Dell'amico E, Cavalca L, Andreoni V (2008) Improvement of Brassica napus growth under cadmium stress by cadmium-resistant rhizobacteria. Soil Biol Biochem 40:74-84

di Toppi LS, Gabbrielli R (1999) Response to cadmium in higher plants. Environ Exp Bot 41:105-130

Drees KP (2004) Quantitative analysis of soil microbial diversity in the hyperarid Atacama Desert, Chile. Dissertation, University of Arizona, pp 52-85

Duruibe JO, Ogwuegbu MOC, Egwurugwu JN (2007) Heavy metal pollution and human biotoxic effects. Int J Phys Sci 2:112-118

Edward Raja C, Selvam GS (2009) Plasmid profile and curing analysis of Pseudomonas aeruginosa as metal resistant. Int J Environ Sci Technol 6:259-266

Edward Raja C, Selvam GS (2012) Characterization of chromosomal mediated cadmium resistance in Pseudomonas aeruginosa strain BC15. J Basic Microbiol 52:175-183

Edward Raja C, Anbazhagan K, Selvam GS (2006) Isolation and characterization of a metal resistant $P$ seudomonas aeruginosa strain. World J Microbiol Biotechnol 22:577-585 
Edward Raja C, Sasikumar S, Selvam GS (2008) Adaptive and cross resistance to cadmium (II) and zinc (II) by Pseudomonas aeruginosa BC15. Biologia 63:461-465

El-Sayed MS, Rehab MM, Ahmed AS (2008) Behavioral response of resistant and sensitive Pseudomonas aeruginosa S22 isolated from Sohag Governorate, Egypt to cadmium stress. Afr J Biotechnol 7:2375-2385

Feng J, Shi Q, Wang X, Wei M, Yang F, Xu H (2010) Silicon supplementation ameliorated the inhibition of photosynthesis and nitrate metabolism by cadmium (Cd) toxicity in Cucumissativus L. Sci Hortic 123:521-530

Filali BK, Taoufik J, Zeroual Y, Dzairi Z, Talbi M, Blaghen M (2000) Waste water bacterial isolates resistant to heavy metals and antibiotics. Curr Microbiol 41:151-156

Gelmi M, Apostoli P, Cabibbo E, Porru S, Alessio L, Turano A (1994) Resistance to cadmium salts and metal absorption by different microbial species. Curr Microbiol 29:335-341

Ghaima KK, Mohamed AI, Meshhdany WYA, Abdulhassan AA (2017) Resistance and bioadsorption of cadmium by Pseudomonas aeruginosa isolated from agricultural soil. IJAES 12:1649-1660

Göksungur Y, Üren S, Güvenc U (2005) Biosorption of cadmium and lead ions by ethanol treated waste baker's yeast biomass. Bioresour Technol 96:103-109

Green SK, Schroth MN, Cho JJ, Kominos SD, Vitanza-Jack VB (1974) Agricultural plants and soils as a reservoir for Pseudomonas aeruginosa. Appl Microbiol 28:987-991

Gupta A, Meyer JM, Goel R (2002) Development of heavy metal-resistant mutants of phosphate solubilizing Pseudomonas sp. NBRI 4014 and their characterization. Curr Microbiol 45:323-327

Haritash AK, Kaushik CP (2009) Biodegradation aspects of polycyclic aromatic hydrocarbons (PAHs): a review. J Hazard Mater 169:1-15

Hassan MET, Van der Lelie D, Springael D, Romling U, Ahmed N, Mergeay M (1999) Identification of a gene cluster, $c z r$, involved in cadmium and zinc resistance in Pseudomonas aeruginosa. Gene 238:417-425

Hassen A, Saidi N, Cherif M, Boudabous A (1998) Resistance of environmental bacteria to heavy metals. Bioresour Technol 64:7-15

Hassen SHA, Gad Abskharon RNN, El-Rab SMF, Shoreit AAM (2008) Isolation, characterization of heavy metal resistant strain of Pseudomonas aeruginosa isolated from polluted sites in Assiut city, Egypt. J Basic Microbiol 48:168-176

Higham DP, Sadler PJ, Scawen MD (1984) Cadmium resistant Pseudomonas putida synthesise novel cadmium proteins. Science 225:1043-1046

Hiroyuki H, Haruyasu R (1980) Comparisons of characteristics of cadmium-tolerant bacterium, Pseudomonas aeruginosa G-I and its cadmium-sensitive mutant strain. Agric Biol Chem 44:777-782

Hossain MA, Hasanuzzaman M, Fujita M (2010) Upregulation of antioxidant and glyoxalase systems by exogenous glycinebetaine and proline in mung bean confer tolerance to cadmium stress. Physiol Mol Biol Plants 16:259-272

Houba C, Remacle J (1980) Composition of the saprophytic bacterial communities in freshwater systems contaminated by heavy metals. Microbial Ecol 6:55-69

Huang J, Liu Z, Li S, Xu B, Gong Y, Yang Y, Sun H (2016) Isolation and engineering of plant growth promoting rhizobacteria Pseudomonas aeruginosa for enhanced cadmium bioremediation. $\mathrm{J}$ Gen Appl Microbiol 62:258-265

Jenni B, Isch C, Aragno M (1989) Nitrogen fixation by new strains of Pseudomonas pseudoflava and related bacteria. J Gen Microbiol 135:461-467

Joutey NT, Sayel H, Bahafid W, El Ghachtouli N (2015) Mechanisms of hexavalent chromium resistance and removal by microorganisms. Rev Environ Contamin Toxicol 233:45-69
Kabata-Pendias A, Pendias H (2001) Trace elements in soils and plants. CRC Press, London

Karimpour M, Ashrafi SD, Taghavi K, Mojtahedi A, Roohbakhsh E, Naghipour D (2018) Adsorption of cadmium and lead onto live and dead cell mass of Pseudomonas aeruginosa: a dataset. Data Brief 18:1185-1192

Kassab DM, Roane TM (2006) Differential responses of a mine tailings Pseudomonas isolate to cadmium and lead exposures. Biodegradation 17:379-387

Kermani JN, Ghasemi MF, Khosravan A, Farahmand A, Shakibaie $\mathrm{R}$ (2010) Cadmium bioremediation by metal-resistant isolated from active sludge of industrial effluent. Iran J Environ Health Sci Eng 7:279-286

Khan NA, Singh SS, Nazar R (2007) Activities of antioxidative enzymes, sulphur assimilation, photosynthetic activity and growth of wheat (Triticumaestivum) cultivars differing in yield potential under cadmium stress. J Agron Crop Sci 193:435-444

Khan NA, Anjum NA, Nazar R, Iqbal N (2009) Increased activity of ATP-sulfurylase and increased contents of cysteine and glutathione reduce high cadmium-induced oxidative stress in mustard cultivar with high photosynthetic potential. Russ J Plant Physiol 56:670-677

Kilic NK, Dönmez G (2008) Environmental conditions affecting exopolysaccharide production by Pseudomonas aeruginosa, Micrococcus sp., and Ochrobactrum sp. J Hazard Mater 154:1019-1024

Kloepper JW, Scroth MN (1978) Plant growth-promoting rhizobacteria on radishes. In: Station de pathologievegetale et phyto-bacteriologie (ed.), Proceedings of the 4th International Conference on Plant Pathogenic Bacteria, Vol. II. Gilbert-Clarey, Tours, France, pp 879-882

Kloepper JW, Rodriguesz-Ubana R, Zehnder GW, Murphy JF, Sikora E, Fernandez C (2001) Plant root-bacterial interactions in biological control of soilborne diseases and potential extension to systemic and foliar diseases. Aust Plant Pathol 28:21-26

Krishna MP, Varghese R, Babu AV, Hatha AM (2012) Bioaccumulation of cadmium by Pseudomonas sp. isolated from metal polluted industrial region. Environ Res Eng Manag 3:58-64

Laddaga RA, Silver S (1985) Cadmium uptake in Escherichia coli K-12. J Bacteriol 162:1100-1105

Lederberg J (2000) Pseudomonas. In: Encyclopedia of microbiology, 2nd edn, vol 3. Academic Pres, San Diego, pp 876-891

Lee SW, Glickmann E, Cooksey DA (2001) Chromosomal locus for cadmium resistance in Pseudomonas putida consisting of a cadmium-transporting ATPase and a MerR family response regulator. Appl Environ Microbiol 67:1437-1444

Lin X, Mou R, Cao Z, Xu P, Wu X, Zhu Z, Chen M (2016) Characterization of cadmium-resistant bacteria and their potential for reducing accumulation of cadmium in rice grains. Sci Total Environ 569-570:97-104

Macaskie LE, Dean ACR, Cheetham AK, Jakeman RJB, Skarnulis AJ (1987) Cadmium accumulation by a Citrobacter sp.: the chemical nature of the accumulated metal precipitate and its location on the bacterial cells. J Gen Microbiol 133:539-544

Maier RM, Soberón-Chávez G (2000) Pseudomonas aeruginosa rhamnolipids: biosynthesis and potential applications. Appl Microbiol Biotechnol 54:625-633

Malik A, Jaiswal R (2004) Metal bioremediation through growing cells. Environ Int 30:261-278

Mangwani N, Shukla SK, Rao TS, Das S (2014) Calcium-mediated modulation of Pseudomonas mendocina NR802 biofilm influences the phenanthrene degradation. Colloids Surf B 114:301-309

McEntee JD, Woodrow JR, Quirk AV (1986) Investigation of cadmium resistance in an Alcaligenes sp. Appl Environ Microbiol $51: 515-520$ 
Mitra RS, Bernstein IA (1977) Nature of the repair process associated with the recovery of Escherichia coli after exposure to $\mathrm{Cd}^{2+}$. Biochem Biophy Res Commun 21:1450-1455

Mobin M, Khan NA (2007) Photosynthetic activity, pigment composition and antioxidative response of two mustard (Brassica juncea) cultivars differing in photosynthetic capacity subjected to cadmium stress. J Plant Physiol 164:601-610

Mohamed RM, Abo-Amer AE (2012) Isolation and characterization of heavy-metal resistant microbes from roadside soil and phylloplane. J Basic Microbiol 52:53-65

Mohan M, Anju N, Santosh P, Dubey K (2012) Pseudomonas aeruginosa strain WI-1 from Mandovi estuary possesses metallothionein to alleviate lead toxicity and promotes plant growth. Ecotoxicol Environ Saf 79:129-133

Mongkolsuk S, Vattanaviboon P, Praitaum W (1997) Induced adaptive and cross-protection responses against oxidative stress killing in a bacterial phytopathogen, Xanthomonasoryzaepv. oryzae. FEMS Microbiol Lett 146:217-221

Müller MM, Kügler JH, Henkel M, Gerlitzki M, Hörmann B, Pöhnlein $\mathrm{M}$ et al (2012) Rhamnolipids-next generation surfactants? J Biotechnol 162:366-380

Mulligan CN (2005) Environmental applications for biosurfactants. Environ Pollut 133:183-198

Muneer B, Iqbal MJ, Shakoori FR, Shakoori AR (2016) Isolation, identification and cadmium processing of Pseudomonas aeruginosa (EP-Cd1) isolated from soil contaminated with electroplating industrial wastewater. Pak J Zool 48:1495-1501

Naik MM, Dubey SK (2011) Lead-Enhanced Siderophore Production and Alteration in Cell Morphology in a Pb-Resistant Pseudomonas aeruginosa Strain 4EA. Curr Microbiol 62(2):409-414

Nakahara H, Ishikawa T, Sarai Y, Kondo I, Kozukue H, Silver S (1997) Linkage of mercury, cadmium, and arsenate and drug resistance in clinical isolates of Pseudomonas aeruginosa. Appl Environ Microbiol 33:975-976

Nath S, Deb B, Sharma I, Pandey P (2014) Role of cadmium and lead tolerant Pseudomonas aeruginosa in seedling germination of rice (Oryza sativa L.). J Environ Anal Toxicol 4:4

Neilson JW, Artiola JF, Maier RM (2003) Characterization of lead removal from contaminated soils by nontoxic soil-washing agents. J Environ Qual 32:899-908

Neilson JW, Zhang L, Veres-Schalnat TA, Chandler KB, Neilson CH, Crispin JD, Pemberton JE, Maier RM (2010) Cadmium effects on transcriptional expression of $r h l B / r h l C$ genes and congener distribution of monorhamnolipid and dirhamnolipid in Pseudomonas aeruginosa IGB83. Appl Microbiol Biotechnol 88:953-963

Nies DH (1992) Resistance to cadmium, cobalt, zinc, and nickel in microbes. Plasmid 27:17-28

Nies A, Nies DH, Silver S (1989) Cloning and expression of plasmid genes encoding resistances to chromate and cobalt in Alcaligenes eutrophus. J Bacteriol 171(9):5065-5070

Nies DH, Silver S (1989) Plasmid-determined inducible efflux is responsible for resistance to cadmium, zinc, and cobalt in Alcaligenes eutrophus. J Bacteriol 171:896-900

Ochoa-Loza FJ, Artiola JF, Maier RM (2001) Stability constants for the complexation of various metals with a rhamnolipid biosurfactant. J Environ Qual 30:479-485

Pacheco SV, Miranda R, Cervantes C (1995) Inorganic-ion resistance by bacteria isolated from a Mexico City freeway. Antonie Van Leeuwenhoek 67:333-337

Pardo R, Herguedas M, Barrado E, Vega M (2003) Biosorption of cadmium, copper, lead and zinc by inactive biomass of Pseudomonas putida. Anal Bioanal Chem 376:26-32

Park SM, Kim SH, Yu TS (2006) Effect of titanium ion and resistance encoding plasmid of Pseudomonas aeruginosa ATCC 10145. J Microbiol 44:255-262
Pellet S, Bigley DV, Grimes DJ (1983) Distribution of Pseudomonas aeruginosa in a riverine ecosystem. Appl Environ Microbiol 45:328-332

Peter AK, Kocsis B, Kilar F, Pernyeszi T (2014) Bio-adsorption characteristics of Pseudomonas aeruginosa PAO1. J Serb Chem Soc 79:495-508

Rajkumar M, Freitas H (2008) Influence of metal resistant-plant growth promoting bacteria on the growth of Ricinus communis in soil contaminated with heavy metals. Chemosphere 71:834-842

Sheng XF, Xia JJ, Jiang CY, He LY, Qian M (2008) Characterization of heavy metal-resistant endophytic bacteria from rape (Brassica napus) roots and their potential in promoting the growth and lead accumulation of rape. Environ Pollut 156:1164-1170

Shi P, Zhu K, Zhang Y, Chai T (2016) Growth and cadmium accumulation of Solanum nigrum L. seedling were enhanced by heavy metal-tolerant strains of Pseudomonas aeruginosa. Water Air Soil Pollut 227:459

Silver S, Phung LT (1996) Bacterial heavy metal resistance: new surprises. Ann Rev Microbiol 50:753-789

Sinha S, Mukherjee SK (2009) Pseudomonas aeruginosa KUCD1, a possible candidate for cadmium bioremediation. Braz J Microbiol 40:655-662

Spain A (2003) Implications of microbial heavy metal tolerance in the environment. Rev Undergrad Res 2:1-6

Tang XY, Zhu YG, Cui YS, Duan J, Tang L (2006) The effect of ageing on the bioaccessibility and fractionation of cadmium in some typical soils of China. Environ Int 32:682-689

Tang X, Zeng G, Fan G, Zhou M, Tang L, Zhu J, Wan J, Huang D, Chen M, Xu P, Zhang C, Lu Y, Xiong W (2018) Chromosomal expression of CadR on Pseudomonas aeruginosa for the removal of Cd(II) from aqueous solutions. Sci Total Environ 636:1335-1361

Tynecka Z, Gos Z, Zajac J (1981) Energy-dependent efflux of cadmium coded by a plasmid resistance determinant in Staphylococcus aureus. J Bacteriol 147:313-319

USEPA (2000) Introduction to phytoremediation. United States Environmental Protection Agency, Washington

Velásquez L, Dussan J (2009) Biosorption and bioaccumulation of heavy metals on dead and living biomass of Bacillus sphaericus. J Hazard Mater 167:713-716

Vijayaraghavan K, Yun YS (2008) Bacterial biosorbents and biosorption. Biotechnol Adv 26:266-291

Volesky B (2001) Biosorption: application aspects process simulation tools. Process Metall 11B:69-80

Wackett LP (2000) Pseudomonas entering the post-genomic era. Environ Microbiol 2:348-354

Wang CL, Michels PC, Dawson SC, Kitisakkul S, Baross JA, Keasling JD, Clark DS (1997) Cadmium removal by a new strain of Pseudomonas aeruginosa in aerobic culture. Appl Environ Microbiol 63:4075-4078

Wuertz S, Mergeay M (1997) Impact of heavy metals on soil microbial communities and their activities. In: Modern soil microbiology. Marcel Dekker, New York, pp 607-642

Xia Y, Liyuan C (2002) Study of gelatinous supports for immobilizing inactivated cells of Rhizopusoligosporus to prepare biosorbent for lead ions. Int J Environ Stud 5:1-6

Yamina B, Tahar B, Lila M, Hocine H, Laure FM (2014) Study on Cadmium Resistant-Bacteria Isolated from Hospital Wastewaters. Adv Biosci Biotechnol 5(8):718-726

Yang XO, Feng Y, He ZL, Stoffella PJ (2005) Molecular mechanisms of heavy metal hyperaccumulation and phytoremediation. J Trace Elem Med Biol 18(4):339-353

Yasemin B, Zek T (2007) Removal of heavy metals from aqueous solution by sawdust adsorption. J Environ Sci 19:160-166 
Zeng X, Tang J, Liu X, Jiang P (2009) Isolation, identification and characterization of cadmium-resistant Pseudomonas aeruginosa strain E1. J Cent South Univ Technol 16:0416-0421

Zeng X, Tang J, Liu X, Jiang P (2012) Response of P. aeruginosa E1 gene expression to cadmium stress. Curr Microbiol 65:799-804

Zhang YX, Song XQ, Huang L, Hu ZQ, Chai TY (2010) Isolation of a cadmium- resistant bacterium from coal mining and heavy metal tolerance. J China Coal Soc 35:1735-1741

Ziagova M, Dimitriadis G, Aslanidou D, Papaioannou X, Tzannetaki EL, Kyriakides ML (2007) Comparative study of Cd(II) and $\mathrm{Cr}(\mathrm{VI})$ biosorption on Staphylococcus xylosus and Pseudomonas sp. in single and binary mixtures. Bioresour Technol 98:2859-2865
Zivkovic LI, Rikalovic M, Cvijovic GG, Kazazic S, Vrvic M, Brceski I, Beskoski V, Loncarevic B, Gopcevic K, Karadzic I (2018) Cadmium specific proteomic responses of a highly resistant Pseudomonas aeruginosa san ai. RSC Adv 8:10549-10560

Publisher's Note Springer Nature remains neutral with regard to jurisdictional claims in published maps and institutional affiliations. 